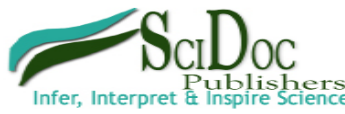

\author{
International Journal of Clinical Pharmacology \& Toxicology (IJCPT) \\ ISSN 2167-910X
}

\title{
The Discovery of Insulin and the Future for Insulin Replacement Therapy
}

Sompop Bencharit

Department of Prosthodontics, School of Dentistry; and Department of Pharmacology, School of Medicine, University of North Carolina at Chapel Hill, Chapel Hill, NC 27599, USA.

Abstract
Adequate consumption of antioxidants, such as vitamin $\mathrm{E}$, is thought to be essential for optimal health. Nutritional surveys
have shown below optimal levels of vitamin $\mathrm{E}$ intake for adults in the United States despite a variety of dietary sources avail-
able. Fortified breakfast cereal is marketed to provide up to $100 \%$ of the daily value for several vitamins and minerals, includ-
ing vitamin $\mathrm{E}$, a known shortfall nutrient. The aim of the study was to determine the effect of consuming a 1 -ounce serving
of fortified breakfast cereal on vitamin $\mathrm{E}$ dietary intake as well as serum tocopherol concentrations among healthy adults.
Forty-two adults completed a 6 -week randomized, controlled, parallel-arm, open-label design (2-week usual diet run-in period
followed by a 4 -week control versus treatment period). The control group (n= 21$)$ consumed and recorded their usual diet
while the intervention group ( $\mathrm{n}=21)$ consumed and recorded their usual diet with the addition of a 1 -ounce serving of forti-
fied breakfast cereal during the 4 -week treatment period. Diet diaries for the 6 -week study period were assessed for accuracy
and analyzed using Nutrient Data System for Research version 2010 . Dietary and serum vitamin $\mathrm{E}$ (alpha-tocopherol) levels
were determined. Mean total vitamin $\mathrm{E}$ dietary intakes at baseline were $8.0+5.5 \mathrm{mg}$ for the intervention group and $7.8+$
4.8 mg for the control group. Total vitamin $\mathrm{E}$ dietary intakes increased in the intervention group to $19.5+5.1$ mg at weeks
3 \& 4 and $19.7+4.3$ mg at weeks $5 \& 6(P<.001 ; P<.001)$ while the control group intake remained unchanged. Mean serum
alpha-tocopherol levels were $0.42+0.31 \mathrm{mg} / \mathrm{dL}$ in the control group and $0.41+0.16 \mathrm{mg} / \mathrm{dL}$ in the intervention group at the
baseline period. Total vitamin $\mathrm{E}$ dietary intakes, but not serum alpha-tocopherol, increased following the 4 weeks of fortified
breakfast cereal consumption.

Keywords: Shortfall Nutrient; Vitamin E; Serum Tocopherol; Fortified Breakfast Cereal.

\section{*Corresponding Author:}

Sompop Bencharit,

Department of Prosthodontics, School of Dentistry; and Department of Pharmacology, School of Medicine, University of North Carolina at Chapel Hill, Chapel Hill, NC 27599, USA.

E-mail: Sompop_Bencharit@dentistry.unc.edu

Received: July 13, 2012

Published: October 01, 2012

Citation: Sompop Bencharit (2012) The Discovery of Insulin and the Future for Insulin Replacement Therapy. Int J Clin Pharmacol Toxicol. 1(1e), 1-2. doi: http://dx.doi.org/10.19070/2167-910X-120001e

Copyright: (C) 2012 Sompop Bencharit. This is an open-access article distributed under the terms of the Creative Commons Attribution License, which permits unrestricted use, distribution and reproduction in any medium, provided the original author and source are credited.

Over 34.6 million people around the world suffer from type 1 diabetes [1]. There is currently no cure for type 1 diabetes and, therefore, patients with this disease require constant care, especially in controlling the level of their serum glucose[1]. Patients with type 1 diabetes nowadays can live an almost normal life with insulin therapy in conjunction with serum glucose monitoring. Before the discovery of insulin, these patients would likely have died from complications of diabetic ketoacidosis. Insulin is a small protein produced by a subgroup of cells called $\beta$-cells in the pancreas located in the islet of Langerhans, named after Paul Langerhans, the German medical student who discovered it in 1869[2]. Soon later, it was found that the absence of pancreas cells, in particular the islet of Langerhans, caused type 1 diabetes [3]. Several attempts were made to use pancreas extract to treat diabetic dogs (induced by removal of pancreas). However, none of these attempts were successful except the one led by Frederick Banting [4]. Banting figured out that the reason why the whole pancreas extract did not work was a result of contamination from the non-islet parenchymal tissue part of the pancreas. With help from J. J. R. Macleod and his summer student, Charles Best, Banting ligated the pancreatic ducts of the dog to induce degeneration of the pancreatic acini, leaving the endocrine islet of Langerhans intact. He then isolated the islet extract and called it "isletin." Isletin, later known as insulin, was used to rescue a pancreatectomized dog named Marjorie. Later they recruited James Collip, a biochemist, who helped them purify isletin from fetal calf pancreas, before the development of pancreatic acini. Banting and Macleod received the Noble Prize in Physiology or Medicine in 1923 and shared their prize with Best and Collip [4]. Insulin protein itself became the first protein to have its amino acid sequence determined by Federick Sanger, who won the Nobel Prize in Chemistry for his work [5]. The three dimensional x-ray crystallographic structure of insulin was determined by Dorothy Crowfoot Hodgkin, who also received the Nobel Prize in Chemistry for the development of protein x-ray crystallography [6].

Insulin is first produced naturally as preproinsulin in the endoplasmic reticulum (ER) of the $\beta$-cell. The preproinsulin is then processed in the Golgi apparatus into proinsulin, which has disulfide linkages between the A, B and C chains of the peptide. The endo- 
peptidases cleave the C-peptide to produce a mature insulin peptide that will be stored in the granule until delivery into circulation [7]. The human insulin forms a hexameric quaternary structure in circulation, which allows for a longer circulation life time [8]. For patients with type 1 diabetes, monomeric forms of insulin are needed because they have virtually no insulin in their system and often need an immediate effect. Various amino acid modifications were used to keep the protein in the active monomeric form [9].

Following the discovery of insulin, it has since been used worldwide and its use had saved millions of lives. Several forms of commercial recombinant insulin proteins are available today. Fortunately, there are limited adverse reactions of using insulin and the frequency of allergic reactions from insulin is low [10]. Use of insulin injection or insulin pumps in combination with self-monitoring of serum glucose allows patients with type 1 diabetes to live an almost normal life. However, this type of treatment does not provide definitive results. Accurate dosing and timely insulin delivery can be difficult. Patients with type 1 diabetes still require constant monitoring and treatment. Patient compliance can also be a issue. For example only about a quarter of patients with diabetes measure their serum glucose daily. The cost of recombinant insulin production, self-monitoring serum glucose device and other diagnostic and monitoring tools can be expensive. The life of diabetic patients depends on the availability of insulin. In the case of a poor third world country plagued with domestic wars or major natural disasters, a disrupted or nonexistent insulin supply can cost lives.

In the past several decades, there has been ongoing research of gene therapy and stem cell therapy to replace insulin-producing $\beta$-cells[11]. The major roadblock in replacing $\beta$-cells in type 1 diabetes is the autoimmune response against new $\beta$-cells. Simple $\beta$-cell replacement is therefore not successful[11]. In addition, there is a need to create a system that allows self-monitoring of serum glucose and timely delivery of insulin based on physiological needs. Recently there is an attempt to use artificial cell encapsulation to protect the stem cell replacement of $\beta$-cells. This encapsulation protects the $\beta$-cell's surface markers and allows stem cells to grow without recognition by the host immune system [12-13]. This type of stem cell replacement may in the near future present a definitive treatment for type 1 diabetes. However, there is still a long road to tie this stem cell advancement with the physiological insulin delivery. The questions remain, "How and where should the encapsulated cells be placed in the body? How will the insulin production and release be regulated?". The discovery of insulin almost a century ago shed light on treatment options and made it possible to manage type 1 diabetes. We are now in the new era of stem cell therapy that shows promise for a definitive cure for this disease.

\section{References}

[1]. World Health Organization. Diabetes Mellitus. (August 2011). Retrieved from http://www.who.int/mediacentre/factsheets/fs312/en/index.html

[2]. islets of Langerhans. (2012). In Encyclopædia Britannica. Retrieved from http://www.britannica.com/EBchecked/topic/329670/islets-of-Langerhans

[3]. Rennie J, Fraser T. The Islets of Langerhans in Relation to Diabetes. Biochem J 1907;2(1-2):7-19.

[4]. Rosenfeld L. Insulin: discovery and controversy. Clin Chem 2002;48(12):2270-88.

[5]. Stretton AO. The first sequence. Fred Sanger and insulin. Genetics 2002;162(2):527-32.

[6]. Glusker JP. Dorothy Crowfoot Hodgkin (1910-1994). Protein Sci 1994;3(12):2465-9.

[7]. Ivanova MI, Sievers SA, Sawaya MR, Wall JS, Eisenberg D. Molecular basis for insulin fibril assembly. Proc Natl Acad Sci U S A 2009;106(45):18990-5.

[8]. Brange J, Langkjoer L. Insulin structure and stability. Pharm Biotechnol 1993;5:315-50.

[9]. Brange J, Owens DR, Kang S, Volund A. Monomeric insulins and their experimental and clinical implications. Diabetes Care 1990;13(9):923-54.

[10]. Silverstein J, Klingensmith G, Copeland K, Plotnick L, Kaufman F, Laffel L, et al. Care of children and adolescents with type 1 diabetes: a statement of the American Diabetes Association. Diabetes Care 2005;28(1):186-212.

[11]. Fiorina P, Voltarelli J, Zavazava N. Immunological applications of stem cells in type 1 diabetes. Endocr Rev 2011;32(6):725-54.

[12]. Kelly OG, Chan MY, Martinson LA, Kadoya K, Ostertag TM, Ross KG, et al. Cell-surface markers for the isolation of pancreatic cell types derived from human embryonic stem cells. Nat Biotechnol 2011;29(8):750-6.

[13]. Schulz TC, Young HY, Agulnick AD, Babin MJ, Baetge EE, Bang AG, et al. A scalable system for production of functional pancreatic progenitors from human embryonic stem cells. PLoS One 2012;7(5):e37004. 